Московский государственный университет имени М. В. Аомоносова / Lomonosov Moscow State University

Россия, Москва / Russia, Moscow

ekorunova@yandex.ru

РЕЦ. НА КН.: Россия и страны Северной Европы: физические и символические границы - Russia and the Countries of Northern Europe: Physical and Symbolic Borders: Cб. ст. V Киркенесского межАународного семинара историков / РеАком.: С. Г. Веригин, А. А. Комаров, Й. П. Нильсен, М. Н. Сумейм, В. В. ТевАина. Петрозаводск: ИзА-во ПетрГУ, 2016. 183 с.; Russia and Norway: Physical and Symbolic Borders / Ed. by T. N. Jackson, J. P. Nielsen. М.: Языки скавянской кумьтуры, 2005. 216 с.

REVIEW OF: Sergey Verigin, Alexey Komarov, Jens Petter Nielsen, Marianne Neerland Soleim, Victoria Tevlina (eds), Rossiza i strany Severnoi Evropy: fizicheskie i simvolicheskie granitsy - Russia and the Countries of Northern Europe: Physical and Symbolic Borders: sbornike statei

V Kirkenesskogo mezhbdunarodnogo seminara istorikov (Petrozavodsk: PetrSU, 2016), 183 p.; Tatjana Jackson, Jens Petter Nielsen (eds), Russia and Norway: Physical and Symbolic Borders (Moscow: Languages of Slavonic culture, 2005), 216 p.

КАючевые слова / Keywords: Российско-норвежские отношения, границы, лимология, Киркенесские семинары, российско-норвежское сотрудничество, «народная Аипломатия» / Russian-Norwegian relations, borders, limology, the Kirkenes seminars, Russian-Norwegian cooperation, «people's diplomacy»

Более семидесяти мет назаА, 14 сентября 1944 г., было подписано Соглашение о перемирии межАу СССР и Великобританией, с одной стороны, и ФинАяндией, с Аругой. По одному из пунктов соглашения, район Петсамо отошел к СССР. В результате у Норвегии и СССР появилась общая граница. Это внесло серьезные изменения в геополитическую обстановку на Европейском Севере и повлияло на характер последующих отношений Авух государств. Такое сосеАство вызывало естественное беспокойство со стороны норвежских политиков, но в то же время у Норвегии появиАся шанс не «смотреть на Советский Союз через финские очки, окрашенные неудачным политическим развитием» и «Аобиваться основанных на доверии отношений» ${ }^{1}$.

Советско-норвежские отношения действительно оживились. Уже после успешного завершения Петсамо-Киркенесской наступательной операции (октябрь 1944 г.) норвежская сторона официально выразила благодарность советскому руководству за вклаА в освобождение оккупированных территорий

\footnotetext{
1 Письмо посла Норвегии в СССР Р. О. Андворда министру иностранных дел Норвегии Т. Аи о будущих советско-норвежских отношениях // Советско-норвежские отношения 1917-1955: Сборник документов / Редкол.: А. О. Чубарьян, У. Ристе, А. А. Комаров, М. А. Коробочкин, И. В. Аебедев, В. В. Рогинский, С. Хольтсмарк, О. М. Эгге. М., 1997. С. 348.
} 
Норвегии от фашистских захватчиков. Норвежский король Хокон VII направиц в алрес главы Президиума Верховного совета СССР М. И. Калинина телеграмму, в которой Аекларировал конец угнетения норвежского народа и восхищался блестящей борьбой советских вооруженных сил за общее дело свободы².

ОАнако ряд спорных моментов, среди которых приоритетное значение име вопрос о судьбах архипелага Шпицберген и острова Медвежий, затормозиц начавшийся процесс политики «наведения мостов», завершившийся в итоге вступлением Норвегии в НАТО в 1949 г. ТогАа у Советского Союза появилась единственная общая граница с Североатлантическим блоком, что не могло не сказаться на характере Авухсторонних отношений Норвегии и СССР.

Потепление в советско-норвежских отношениях наметилось только после визита норвежского премьер-министра Эйнара Герхардсена в СССР в ноябре 1955 г. Спустя несколько месяцев МИА СССР подготовило «Указание послу СССР в Норвегии», в котором подчеркивалась необходимость «развития и укрепления Аружественных, добрососеАских отношений межАу СССР и Норвегией и ослабление связей с Североатлантическим блоком»³.

Не прошло и года, как события в Венгрии снова приостановили процесс сближения Авух стран. ОАнако стремление к конструктивному Аиалогу, которое не прекращалось никогда, одержало вверх наА обоюдными страхами и недоверием. Оно нашло выражение в официальном поездке Н. С. Хрущева по Скандинавии, когда он в 1964 г. посетил и Норвегию. Взаимоотношения Авух соседей вновь претерпели определенную эволюцию. Новый импульс получили политические, экономические и культурные связи стран. Подобная «политика дипломатических качелей» была характерна Аля советско-норвежских отношений на протяжении всего XX в.

Паралмельно политической минии формировалась так называемая народная Аипломатия, которая традиционно играла особую роль во взаимоотношениях Авух государств. Население по обе стороны границы всегда ощущали особую общность и потребность в более тесном сотрудничестве. Как заметил генеральный консул Королевства Норвегия в Мурманске Э. Нордслеттен (2011-2013): «“Народная дипломатия” дала многое. Это не миф, а факт, который подтверждается кажАый Аень» ${ }^{4}$.

\footnotetext{
2 Поздравительная телеграмма короля Норвегии Хокона VII М. Калинину // Вестник Архива Президента Российской Федерации. Война: 1941-1945. М., 2010. С. 387.

3 Архив внешней политики Российской Федерации (АВП РФ) Ф. 0116. Оп. 45. П. 183. А. 1. А. 2.

${ }^{4}$ Из интервью с Генеральным Консулом Королевства Норвегия в Мурманске Э. НорАслеттеном // Баренц-сборник: Региональное межвузовское научное издание. Мурманск, 2013. Вып. 1 (01). 20метие Баренцева Евро-Арктического сотрудничества: Сб. статей и материалов. С. 20.
} 
Аействительно, XXI в. с его глобализацией и ранее невиАанными темпами развития технологических возможностей изменил традиционное представление о границах между государствами. Еще недавно, в начале 2000-х гг., учёные занимались изучением межгосударственных границ в трёх плоскостях: территория, гражданство и орган государственной власти. Но уже тогда высказывацась точка зрения, что границы бывают не только физические, но и символические. Так, например, учреждение Баренцева Евро-Арктического региона стало своеобразным ответом на имеющиеся трансграничные контакты на севере. Аеятельность в рамках БЕАР способствоваца возрождению и развитию межАународных связей «четырёх стран северо-западного угла Европы» и создало межАу ними благоприятную атмосферу сотрудничества 5 . На рубеже веков значительным образом укрепились научные контакты, нашедшие выражение в совместной деятельности историков Университета Тромсё и их российских колмег из Архангельска, Мурманска, Москвы и других городов Российской Федерации.

Всё это наилучшим образом вписывается в новое понятие «лимология» ${ }^{6}$, принятое в послеАние Аесятилетия на вооружение специалистами, которые занимаются политической географией. Являясь межАисциплинарной наукой, Аимология способна наиболее широко охватить весь спектр отношений в БЕАР, гАе присутствуют понятия культурных, цивилизационных, экономических, Аемографических и Аругих границ. Аанная наука определяет важность пограничных районов Аля культурной коммуникации межАу народами и нациями. Благодаря своей «многослойности», Аимология стала межАисциплинарным направлением, рассматривающим отдельные регионы, которые существуют вне политической Аействительности, по принципу «мир без границ».

Ярким примером такой коммуникации, благодаря которой изучаются как государственные границы на разных этапах истории, так и политическое и социокультурное пространство приграничных территорий, а также развивающиеся на них политико-территориальные процессы, стало проведение крупной конференции по проблемам русско-норвежских отношений в СанктПетербурге в 2005 г. с последующим изданием сборника статей. Встреча была приурочена к открытию международной выставки «Россия-Норвегия: сквозь века и границы». Торжественно открытая генеральным консулом Норвегии в Санкт-

\footnotetext{
5 Миклебост К., Голдин В. И. Асимметричное соседство глазами историков: К 20-летию Киркенесской Аекмарации. // Янтарный мост. 2013. № 1 (9). С. 42. URL: http://ambbr.artinfo.ru:8008/userfiles/file/amberjournal/issue9/rus/06-sosedstvo.pdf (24.12.2018).

${ }^{6}$ Аимология (от мат. limes 'граница') — научная дисциплина, изучающая природу и функции границ, приграничные территории (регионы), пограничные институты, а также приграничные процессы.
} 
Петербурге Отто Мамелундом (2003-2008) конференция привлекла серьезное внимание российских и зарубежных СМИ.

В том же гоАу увиАел свет подготовленный усилиями российских и норвежских историков сборник «Россия-Норвегия: физические и символические границы». Его редакторами выступили А. и. н., сотрудник Института всеобщей истории РАН (ИВИ РАН) Татьяна Николаевна Ажаксон и профессор Университета Тромсё (Арктического университета Норвегии) Йенс Петтер Нильсена (Jens Petter Nielsen) 7.

В предисловии Т. Н. Ажаксон и Й. П. Ницьсен, указали, что глубокая разница в подходах к политическому устройству, несовпадение религий и наличие множества культурных барьеров по всей могике мироустройства должны были бы привести к конфликтам межАу двумя народами. Тем не менее российско-норвежское Авухстороннее сотрудничество на Севере имело преимущественно мирный характер на протяжении многих столетий 8 .

К участию в сборнике были привлечены известные в своей области учёные из Норвегии, Аании, Великобритании и России. Скандинавию представляли Карстен Папе (Carsten Pape), Аарс Ивар Хансен (Lars Ivar Hansen), Эйнар Ниеми (Einar Niemi), Астри Анцресен (Astri Andresen), Эрик Эгеберг (Erik Egeberg), Кари Мюклебуст (Kari Myklebost), Свен Хольтсмарк (Sven Holtsmark) и ИнгриА Квальвик (Ingrid Kvalvik). Из российских учёных приняли участие В. В. Рогинский, Т. А. Шрадер, Р. В. Пересадило, А. В. Познанская, А. Ю. Юрченко, Т. П. Тетеревлева, А. А. Комаров и А. В. Репневский. Тематика статей сборника широка и охватывает периоды от раннего Средневековья и до 90-х гг. ХХ столетия. Авторы издания продемонстрировали, что в богатой разнообразием истории отношений межАу Авумя народами границы могут становиться подвижными и пересекаться в разАичных плоскостях. Это, в частности, хорошо показывает открывающая сборник статья Й. П. Нильсена «Размышления о норвежско-русской границе и эволюции государственной границы в целом», которая посвящена теоретическим аспектам, анализу понятий border и frontier, а также динамике развития отношений, связанных с норвежско-русской границей сквозь века9.

Традиция, заложенная учёными в начале 2000-х, не прервалась. Благодаря Аеятельности историков в рамках регулярно-проводимых Киркенесских семинаров, возникла идея продолжить обсужАение вопросов российско-скандинавских Отношений сквозь столетия и развить Аискуссию о характере российско-норвежской границы. Первый семинар состоялся в 1999 г. в Мурманске и был посвящён истории

\footnotetext{
${ }^{7}$ Russia and Norway: Physical and Symbolic Borders / Ed. by T. N. Jackson, J. P. Nielsen. Moscow, 2005.

8 Preface // Ibid. P. 6.

9 Nielsen J. P. Some Reflections on the Norwegian-Russian Border and the Evolution of State Borders in General // Ibid. P. 7-16.
} 
международных отношений на Севере Европы. Следующий семинар, на котором учёные поАняли волнующую тему сотрудничества и конфликтов в Арктике в XIXХХ вв., организовывался норвежской стороной и проходил в Киркенесе в 2002 г. Именно тогАа возникла идея проводить встречи учёных на регулярной основе.

К активной деятельности были привлечены крупные научно-образовательные центры, институты и университеты Норвегии и России. География участников семинаров была весьма обширна. При этом важно отметить, что все городаучастники (за исключением Москвы) представляли собой столицы аАминистративных областей, входящих в состав Евро-Арктического Баренц региона. Состоявшиеся в 2007 и 2009 гг. III и IV межАународные семинары закрепили траАицию встреч учёных.

На V Киркенесском международном семинаре в Петрозаводске, который прошёл шесть мет спустя (в 2015 г.), снова собрались как учёные, ранее принимавшие участие во встречах, так и молодые специалисты, присутствие которых свилетельствовало о глубоком интересе к проблемам российсконорвежских проблем среди нового поколения скандинавистов. Выступая переА собравшимися, министр образования Республики Карелия и историк по образованию А. Н. Морозов подчеркнул необходимость углубленного изучения вопросов, касающихся российско-норвежских отношений в целом и проблемы границы в частности. Он выразил точку зрения, что границу нельзя рассматривать исключительно как Аинию, разделяющую народы. На границе происходит своеобразная «гуманитарная диффузия», выражающаяся в проникновении культур, обрядов, архитектуры, гуманитарных состав яющих от одного народа к Аругому ${ }^{10}$.

V Киркенесский семинар придац новый импульс научным контактам. Именно тогАа зародицась илея публикации на русском языке большой колмективной монографии по истории российско-норвежских отношений, к написанию которой были привлечены ведущие специалисты из обеих стран и которую издательство «Весь Мир» выпустило в свет в 2017 г. под названием «Сближение. Россия и Норвегия в 1814-1917 годах» ${ }^{11}$.

\footnotetext{
10 «В ПетрГУ начал работу V Киркенесский межАународный семинар историков на тему "Россия и страны Северной Европы: физические и символические границы”» [Электронный ресурс]. URL: http://old.petrsu.ru/print.html?action=preview\&id=16298 (4.09.2018).

11 Сближение: Россия и Норвегия в 1814-1917 годах / Пер. с норв.; под ред. Й. П. Нильсена. M., 2017.
} 
Непосредственно же по итогам встречи в Петрозаводске был подготовлен сборник статей «Россия и страны Северной Европы: физические и символические границы», опубликованный в 2016 г. ${ }^{12}$

Сборник открывается статьёй профессора Петрозаводского государственного университета (ПетрГУ) А. М. Пашкова об историко-культурном наследии Русского Севера $^{13}$. Благодаря творчеству деятелей русского искусства периода «серебряного века» Аля послеАующих поколений были открыты великие Аостояния русского деревянного зодчества, ставшие, как утверждает автор, важнейшим элементом русского национального самосознания ${ }^{14}$. Статья ицлюстрирует наилучшие проявления историко-культурного наследия Европейского Севера России и подтвержАает глубину взаимного проникновения в культуру населяющих регион народов.

Общий фон российско-норвежских отношений в XIX - начале XX в. представлен в статье к. и. н. А. С. Касиян ${ }^{15}$. Автор Ааёт характеристику Авухсторонним отношениям и ставит перед собой задачу определить последствия возникновения в 1826 г. российско-норвежской границы.

РяА учёных, занимающиеся русско-норвежской конвенцией 1826 г., обратили внимание на историографию вопроса. Так, в статье доцента В. В. Ефимовой на основании анализа Авух работ Аиректора Арктического центра стратегических исследований Северного (Арктического) федерального университета им. М. В. Аомоносова (САФУ) К. С. Зайкова отстаивается мнение, что в изучении истории заключения конвенции ставить точку пока еще рано ${ }^{16}$.

Той же позиции придерживается и известный норвежский учёный Й. П. Нильсен. Он значительно расширяет рамки интерпретации этой границы, которая, по его мнению, являлась результатом эволюции, характерной Аля Европы в целом, но в то же время в некоторых отношениях и отклонялась от общей закономерности. Автор особо подчёркивает, что «А^я небольшого государства широкая пограничная зона, или “ничейные” земли», могли стать источником беспокойства и конфликта, поэтому неопределенность в вопросе территориальной

12 Россия и страны Северной Европы: физические и символические границы Russia and the Countries of Northern Europe: Physical and Symbolic Borders: Сб. ст. V Киркенесского межлународного семинара историков / Редкол.: С. Г. Веригин и Ар. Петрозаводск, 2016. 183 с.

${ }^{13}$ Пашков А. М. Пограничные столбы Русского мира: деревянная архитектура Поморья и ее изучение в период «серебряного века» // Там же. С. 16-25.

14 Там же. С. 23.

${ }_{15}$ Касиян A. C. Некоторые особенности российско-норвежских отношений на Севере в XIXначале XX века // Там же. С. 60-69.

${ }_{16}$ Ефимова В. В. К вопросу о степени изученности истории подготовки и заключения руссконорвежской Конвенции 1826 года о границе / / Там же. С. 70-74. 
протяжённости, продолжавшаяся в течение АОАгого времени, привносила в отношения Авух соседей осторожность и определённое недоверие ${ }^{17}$.

В статье К. С. Зайкова преАставлен краткий обзор российских и европейских исследований по теме приграничья и, в частности, содержится полемический анализ упомянутой выше статьи $\quad$ В. В. Ефимовой. Кроме того, К. С. Зайков рассказывает об исторической традиции восприятия договора 1826 г. в Норвегии ${ }^{18}$.

Нельзя не отметить, что вопросы, касающиеся конвенции 1826 г., волновали учёных и ранее. В сборнике 2005 г. этой проблематике также было посвящено несколько исследований, в частности, сотрудника ИВИ РАН, профессора В. В. Рогинского, историка из Бергена Астри Андресен и историка из Кембриджа Мари Ишизука' ${ }^{19}$.

Историографический обзор по ряду вопросов, связанных с развитием российско-норвежского сотрудничества в сфере исторических исслеАований, представиц директор научно-образовательного центра «МежАународные отношения и арктическая политика России»н на базе САФУ А. В. Репневский ${ }^{20}$. Он перечислил позитивные моменты Авадцатипятилетнего опыта Авухстороннего сотрудничества историков на современном этапе взаимоотношений.

ОтАельное внимание традициям в сфере цокальной и региональной истории в Тромсё, Мурманске и Архангельске уделил докторант Университета ТромсёАрктического университета Норвегии У. Г. Андерссон (O. G. Andersson) ${ }^{21}$.

Историографический блок подытожили $\mathrm{PhD}$, Аиректор Баренц-института Университета Тромсё M. Н. Сулейм (M. N. Soleim) и А. и. н, Аоцент того же Баренцинститута В. В. Тевлина. В продолжение темы, заАанной колмегой из Архангельска профессором Репневским, В. В. Тевлина описала методы и особенности подготовки калров-историков в Норвегии и России 22 , в то время как М. Н. Сулейм предложила краткий обзор исслеАований и научных обменов, касающихся приграничья,

\footnotetext{
17 Нильсен Й. П. Запоздалая, но стабильная... Норвежско-российская государственная граница 1826 года // Там же. С. 53-59.

18 Зайков К. С. История российско-норвежского пограничья в свете российской и европейской историографии // Там же. С. 75-90.

${ }^{19}$ Roginsky $V$. The 1826 Delimitation Convention between Norway and Russia: A Diplomatic Challenge // Russia - Norway. P. 62-68; Andresen A. States demarcated - People Divided: the Skolts and the 1826 Border Treaty // Ibid. P. 80-94; Ishizuka M. Norwegian-Russian Borderland in Transition: Spatial Perception among Norwegian Elites in 1826-1852 // Ibid. P. 95-104.

20 Репневский A. B. 25 мет сотрудничества: вехи на пути к межАународному проекту «Асимметричное сосеАство: Норвегия и Россия 1814-2014» // Россия и страны Северной Европы. С. 163-174.

21 Andersson O. G. Local and Regional Historical Research in the Russian and Norwegian North: The Turn to the Border // Там же. C. 143-150.

${ }^{22}$ Тевлина В. В. Исторические исследования, подготовка историков и межграничное сотрудничество: опыт России и Норвегии // Там же. С. 151-162.
} 
с акцентом на партнеров не только в России, но и в США, Канаде и ФинАяндии 23. ЗаАачей статьи было понять, какие возможности скрываются за практикой международного партнерства в этом направлении. В свою очередь, В. В. Тевлина постаралась исследовать системность в работе наА межАународными изданиями с целью создания необходимых условий Аля успешной реализации совместных проектов в буАущем.

Новаторской с точки зрения введения новых источников в научный оборот представляется статья Аоцента ПетрГУ И. А. Черняковой и главного специалиста издательства ПетрГУ О. В. Чернякова 24.

Проблемам урегулирования вопроса о советско-финской границе на завершающем этапе и после Второй мировой войны посвящены Аве статьи сборника, авторство которых принадлежит профессору, Аиректору Института истории, политических и социальных наук ПетрГУ С. Г. Веригину ${ }^{25}$ и к. и. н., в. н. с., руководителю Центра истории Северной Европы и Балтии ИВИ РАН А. А. Комарову ${ }^{26}$.

Статья Аоцента ПетрГУ Г. В. Чумакова посвящена главным образом Аеятельности Союзной контрольной комиссии в ФинлянАии в 1944-1945 гг. Автор даёт оценку роли председателя комиссии А. А. ЖАанова в деле подписания соглашения межАу СССР и Финляндией на завершающем этапе Второй мировой войны. Г. В. Чумаков не только затрагивает проблемы демаркации границы, но и уделяет особое внимание экономической составцяющей отношений межАу Авумя государствами-соседями. На основе Аокументов Российского государственного архива социально-политической истории он показывает наличие у советских Аипломатов заинтересованности в выстраивании прочных экономических связей с Финляндией заАолго до подписания советско-финляндского Аоговора о Аружбе, сотрудничестве и взаимной помощи в апреле 1948 г. ${ }^{27}$

Историки из Мурманска (Аоцент Института экономики В. А. Карелин) и начальник отдела истории Мурманского областного краеведческого музея (Е. А. Орехова) затронули важные темы, связанные с проблемой саамских сервитутов

\footnotetext{
${ }_{23}$ Soleim M. N. Knowledge Production and Capacity Building on the Social Science of Borderlands and the High North // Там же. C. 175-180.

24 Чернякова И. А., Черняков О. В. (Не)известная старая карта как источник о состоянии российскошведской границе в конце XVIII века // Там же. С. 34-52.

25 Веригин С. Г. Аемаркация советско-финляндской границы по мирному договору 12 марта 1940 г. (по источникам из фондов центральных российских архивов) // Там же. С. 118-124.

${ }_{26}$ Комаров $A$. A. К вопросу о восстановцении советско-норвежской границы в результате Второй мировой войны // Там же. С. 132-142.

27 Чумаков Г. В. Аеятельность А. А. ЖАанова в ФинАяндии на заключительном этапе Второй мировой войны // Там же. С. 125-131.
} 
в истории российско-норвежских пограничных отношений нача^а $\mathrm{XX}$ в., а также понятием «граница» в отношении Мурманского берега28.

В целом, появление Авух сборников, которые разделяет целое Аесятилетие, свидетельствует о сложившихся академических традициях, заложенных учёными России и Норвегии в постбиполярную эпоху. Изучение различных аспектов жизнедеятельности Аруг Аруга, обмен знаниями и опытом в вопросах восприятия общих исторических тем, попытки взглянуть на исследовательские проблемы под разным углом зрения - всё это нашло отражение в Авух преАставленных изАаниях. В сборниках прослеживается научная преемственность: многие участники только начинали свой путь в качестве историков-скандинавистов в начале 2000-х гг., а в 2015 г. на V Киркенесском международном фестивале выступали уже признанными специалистами в своей области.

Постоянство в подАерживании контактов, осуществцяемое на протяжении многих мет историками Й. П. Нильсеном, А. А. Комаровым, С. Г. Веригиным, А. В. Репневским, В. В.Тевлиной, М. Н.Сулейм и многими Аругими, обеспечили как проведение семинаров и выход указанных сборников, так и способствовали развитию связей в гуманитарных области межАу Норвегией и Россией, Аоказывая своей работой эффективность «народной Аипломатии».

\section{Список митературы}

Миклебост, К. Асимметричное соседство глазами историков : к 20-летию Киркенесской декларации / К. Миклебост, В. И. Голдин // Янтарный мост. - 2013. - № 1 (9). — С. 40 47. — URL: http://ambbr.artinfo.ru:8008/userfiles/file/amberjournal/issue9/rus/06-sosedstvo.pdf. (24.12.2018).

Сближение: Россия и Норвегия в 1814-1917 годах / пер. с норв. ; под реА. Й. П. Нильсена. — Москва : Весь Мир, 2017. - 708 с.

${ }_{28}$ Карелин В. А. О проблеме саамских сервитутных прав в межпограничных отношениях России и Норвегии (1826 - начало XX века) // Там же. С. 91-102.; Орехова Е. А. Мурманский берег. Колонизация 1860-1940: границы реальные и символические // Там же. С. 103-107. 